15. Suchkova E. V. The functional condition of the hepato-biliary system in fatty hepatosis with concomitant diabetes mellitus / E. V. Suchkova // Eksp. Klin. Gastroenterol. - 2009. - Vol. 8. - P. 2629.

16. Mato J. M. Methionine metabolism and liver disease / J. M. Mato, M. L. Martinez-Chantar, S. C. Lu // Annu. Rev. Nutr. - 2008. - Vol. 8. - P. 273-293.

17. Lokes P. I. Ultrazvukova diahnostyka chvorob tvaryn / P. I. Lokes, V. H. Stovba, L. P. Karysheva. - Poltava : FOP Hovorov S. V., 2007. - 128 s. [in Ukrainian].

Рецензент - Н. І. Дмитренко, к. вет. н., доцент, Полтавська державна аграрна академія.

УДК 619:631.95:631.461:648.6:614.48

doi: $10.36359 /$ scivp.2019-20-2.56

\title{
АНАЛІЗ РИНКУ ДЕЗІНФІКУЮЧИХ ЗАСОБІВ В УКРАЇНІ
}

\author{
O. I. Касяненко, д-р вет. наук, професор, \\ А. В. Березовський, д-р вет. наук, професор, \\ С. М. Касяненко, аспірант, \\ Р. В. Долбоносова, канд. вет. наук
}

Сумський національний аграрний університет, вул. Герасима Кондратьєва, 160, м. Суми, 40021, Україна

У статті наведені результати аналізу сучасного ринку дезінфікуючих засобів за активно діючими речовинами. На основі даних державного реєстру ветеринарних препаратів, кормових добавок, готових кормів та преміксів щодо зареєстрованих дезінфікуючих засобів та їх рецептур встановлено, щуо кількість препаратів для дезінфекції $i$ санації об'єктів ветеринарно-санітарного нагляду понад 200 найменувань, в тому числі вітчизняного $i$ зарубіжного виробництва. Найбільща частка засобів представлена пінними $i$ безпінними лужними засобами - 31,43 \%, пінні і безпінні кислотні засоби - 22,86 \%, дезінфектанти на основі четвертинних амонійних сполук (ЧАС) - 15,71\%, спиртові- 6, 19\%, кисневмісні дезінфектанти - 5,24\%, гуанідинові-4,76\%, засоби на основі альдегідів - 4,76\%, хлорвмісні засоби - 4,29\%. Асортимент засобів дезінфекиї на вітчизняному ринку має тенденцію до збільшення.

Ключові слова: ДЕЗІНФІКУЮЧІ ЗАСОБИ, АКТИВНО ДІЮЧІ РЕЧОВИНИ, ПАТОГЕНИ, ЗАСТОСУВАННЯ, ЕФЕКТИВНІСТЬ.

Актуальним питанням сучасної ветеринарної медицини є розробка та застосування біологічно ефективних, екологічно безпечних i конкурентоспроможних дезінфікуючих засобів. Застосування дезінфектантів є одним із пріоритетних заходів ветеринарно-гігієнічних програм профілактики та ліквідації інфекційних хвороб тварин та птиці $[3-5,8]$.

Згідно із Законом України «Про основні принципи та вимоги до безпечності та якості харчових продуктів» (в редакції Закону № 1602-VII від 22.07.2014), II. Ст. 8 державна політика у сфері безпечності та якості харчових продуктів грунтується на здійсненні державного контролю за впровадженням постійно діючих процедур, заснованих на принципах НАССР [2]. Обов'язкове впровадження системи аналізу ризиків та контролю безпечності продуктів 
тваринництва у критичних точках - НАССР на підприємствах-операторах ринку «від лану до столу» здійснюється лише за умови реалізації програм-передумов, що включають правила GMP (належна виробнича практика) та GHP (належна гігієнічна практика). Використання деззасобів деяких груп упродовж тривалого часу може призвести до формування стійкості (резистентності) до нього мікроорганізмів. Ефективність реалізації вищевказаних програм підвищується на основі впровадження системи моніторингу і методів контролю чутливості патогенів до дезінфікуючих засобів, що застосовуються. Аналіз даних сучасного ринку дезінфікуючих засобів на основі активно діючих речовин надасть потенційну можливість застосовувати ефективні схеми ротації та досягати максимальної ефективності дезінфекції об’єктів ветеринарно-санітарних заходів [6, 7, 9-14].

Матеріали і методи. Наукові дослідження проводили згідно з пріоритетним напрямом, регламентованим постановою Кабінету Міністрів України від 07.09.2011 № 942 «Науки про життя, нові технології профілактики та лікування найпоширеніших захворювань» у відповідності до тематичного плану науково-дослідної роботи кафедри ветсанекспертизи, мікробіології, зоогігієни та безпеки і якості продуктів тваринництва Сумського НАУ «Система моніторингу методів контролю та ветеринарно-санітарних заходів щодо якості й безпеки продукції тваринництва при хворобах заразної етіології», (номер державної реєстрації 0114U005550, 2014-2019 рр.). Теоретичне узагальнення та експериментальне розв'язання наукової проблеми проводили на основі аналізу даних державного реєстру ветеринарних препаратів, кормових добавок, готових кормів та преміксів щодо зареєстрованих дезінфікуючих засобів та їх рецептур [1]. Також аналізували матеріали наукових публікацій, інформування засідань фармакологічної комісії, а також повідомлення про результати проведення тендерних закупівель ветеринарних препаратів провідними агропромисловими підприємствами в 2017-2018 рр.

Результати й обговорення. За даними державного реєстру ветеринарних препаратів, кормових добавок, готових кормів та преміксів, кількість препаратів для дезінфекції і санації об’єктів ветеринарно-санітарного нагляду постійно збільшується. Асортимент дезінфікуючих засобів включає різні групи хімічних сполук, за складом яких комерційні препарати поділять на групи. На рисунку представлено співвідношення дезінфікуючих засобів на ринку України відносно активно діючих речовин.

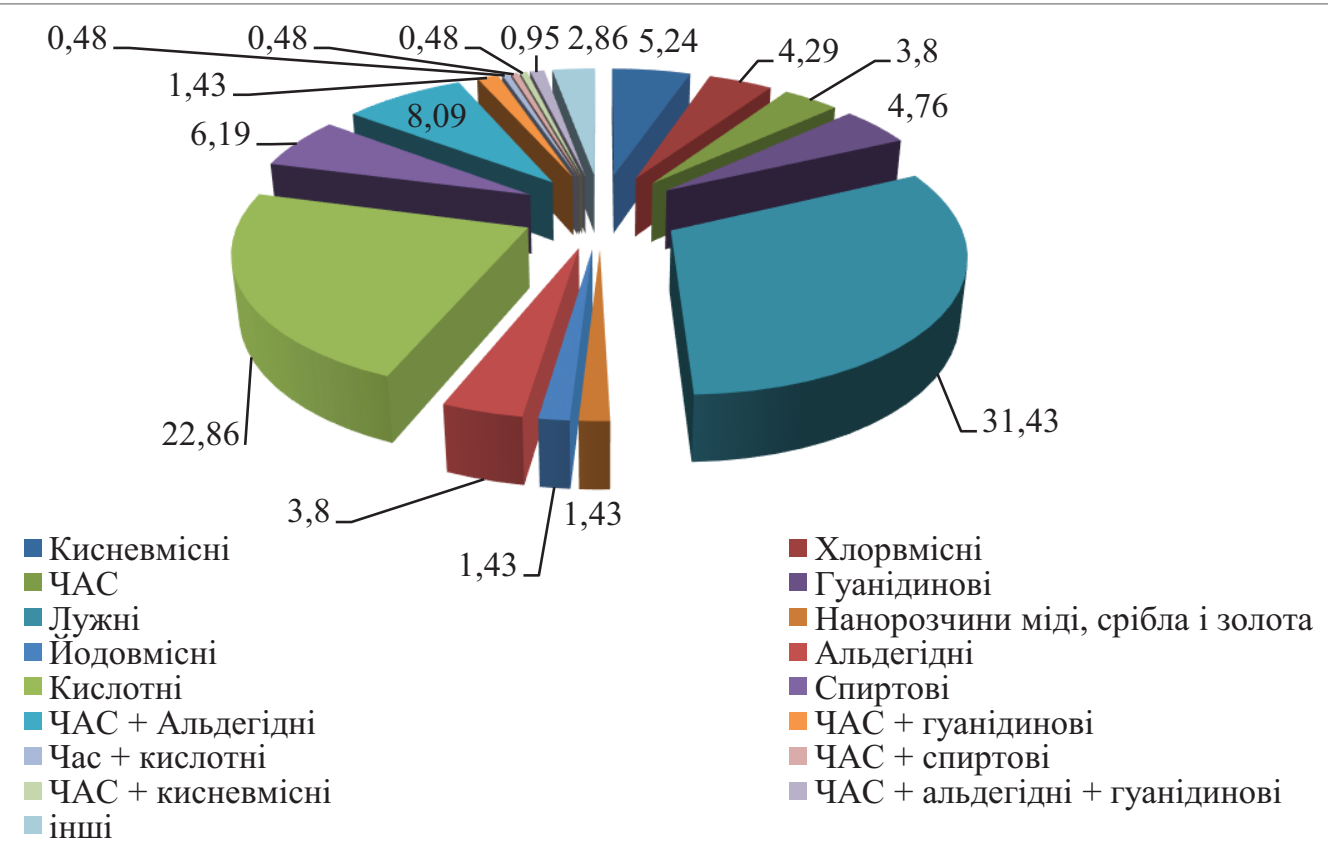

Рис. Часка дезінфікуючих засобів за групами діючих речовин на ринку України, \% 
Кількість дезінфікуючих засобів за групами діючих речовин на ринку України понад 210 найменувань як вітчизняного, так і зарубіжного виробництва.

Найбільша частка препаратів представлена пінними і безпінними лужними засобами. Їх кількість складає 66 найменувань $(31,43 \%)$ в тому числі 17 вітчизняного виробництва (OXIN ® LD 201, OXIN ® LV 210, Эксан-Про-Дез, Контакт, Supra, Сантана ДЕ3, Басікс, Ultima active, Сантек (ДЕЗ), Fortis, Multisteril sansanit та ін.).

Майже 22,86 \% (48 найменувань) асортименту ринку України представляють пінні і безпінні кислотні деззасоби. Із загального числа кислотних деззасобів 20 засобів $€$ вітчизняного виробництва. Асортимент представлений засобами: Сантек К7, Бланідас-А Ацид, Акваклин, Ацетик, Сандим-Д, Делаксон, Биолюфт, Дезокс, СІД 2000, НРРА, Селко, П3оксонія актив 150, Унівайт, Оргасепт та ін. Препарати даної групи добре очищають поверхні від органічних забруднень, мають широкий спектр дії та мікробіоцидний ефект, добре розчиняються у воді, утворюють в повітрі і воді активні суспензії, емульсії, тумани і аерозолі. Вони здатні до тривалої активності в середовищі, не пошкоджують поверхні об’ єктів, а також мають низьку токсичність та алергічну дію. Слід зазначити, що соляна кислота не рекомендується для контролю вірусних захворювань, надзвичайно токсична та проявляє корозійні властивості щодо поверхонь, що обробляються $[2,5,7,8]$.

У ветеринарній практиці широко застосовують кисневмісні дезінфекційні засоби (11 найменувань - 5,24 \%). Активно діючими речовинами є активний кисень у складі перекису водню, перекисних сполук, надкислот, перборати, озон та композиційні засоби на їх основі (Пероксимед, Виркон, Сантек, Делаксон, Біолюфт, Дезокс, Екоцид, Унівайт, Оргасепт та ін.). Найсильнішими активаторами перекису водню $є$ мурашина, молочна, щавлева i оцтова кислоти. Більшість засобів не має запаху, але кородують метали. Дані засоби мають широкий спектр антимікробної активності та проявляють здатність розчиняти біологічні субстрати. В навколишньому середовищі розпадаються на екологічно безпечні речовини. Активні при низьких та високих температурах $[5,9,11]$.

Дещо менше представлені на ринку України дезінфікуючі засоби на основі альдегідів. Використовуються для дезінфекції формальдегід, гліоксалевий і глутаровий альдегід активно діючі речовини вітчизняних і закордонних препаратів. На вітчизняному ринку 10 засобів, що складає 4,76 \%. Засоби даної групи $є$ високоактивними сполуками 3 широким антимікробним спектром дії. Широкого застосування набули 3 \% розчин формальдегіду (мурашковий альдегід, метаналь), Біоконтакт, Дезоформ, Метафор, Лізоформін ветеринарний, Формаз, Кристал 900, Кристал 1000, Дезоформ, Сайдекс, Кліндезін 3000. Не проявляють корозійних властивостей та негативного впливу на пластмасу, дерево і гуму. Засоби даної групи є канцерогенами, високотоксичні і швидко інактивуються у зовнішньому середовищі, особливо за низьких температур, не рекомендуються для контролю небезпечних вірусних захворювань, діють у разі високої концентрації $[3,4,12]$.

Високою антимікробною активністю володіють хлорорганічні сполуки. На ринку України вони представлені 9 препаратами (4,29\%), лише три з яких вітчизняного виробництва. Хлорорганічні сполуки володіють високою антимікробною активністю, основою якої $\epsilon$ процеси окиснення, денатурація білка та нуклеїнових кислот. На практиці широко застосовується хлорне вапно, гіпохлорит натрію та кальцію, гіпохлор, Хлорамін Т, Halamid, натрію дихлорізоцианурат та ін. Препарати цієї групи мають удосконалену форму випуску, що забезпечує нівелювання їх негативних властивостей. У великих концентраціях хлорорганічні сполуки застосовують для контролю вірусних захворювань. Недоліками $\epsilon$ низька активність у присутності органічних речовин, подразнююча дія на зовнішні покриви $\mathrm{i}$ слизові оболонки, корозійні властивості щодо м'яких металів та екологічна небезпека $[5,6]$.

Значну групу (близько 33 препаратів - 15,71 \%) представляють дезінфектанти на основі четвертинних амонійних сполук (ЧАС), які складаються з вуглеводного радикалу, метального, етильного або бензольного радикалу, хлору, брому, йоду. Найпоширенішими $\epsilon$ 
алкілдиметилбензиламоній хлорид, діоктилдиметиламоній хлорид, дідецилметиламоній хлорид. На ринку понад тридцяти активних композиційних сполук: (ЧАС + альдегідні - 17 $(8,09 \%)$, ЧАС + гуанідинові $-3(1,43 \%)$, ЧАС + кислотні - $1(0,48 \%)$, ЧАС + спиртові -1 $(0,48 \%)$, ЧАС + кисневмісні - 1 (0,48 \%), ЧАС + альдегідні та гуанідинові - 2 (0,95\%). Найбільше практичне значення мають деззасоби: Камамін Б, Септодор, Біоклін, Декаметоксин, Септабік, Глутарпін, Roccal-D, Vetrequat, Mikro-Quat, Fulsan, Aquasan та ін. Дані препарати володіють гарними миючими властивостями, низькою токсичністю, відсутністю різкого запаху, не викликають корозії поверхонь, водорозчинні, стабільні при зберіганні. Недоліком даних препаратів є вузький спектр антимікробної активності, який вирішуються шляхом додаванням глутарового альдегіду до їх рецептур $[11,13,14]$.

Із групи спиртових засобів широко використовують засоби на основі композицій ізопропілового та етилового спиртів, пропанолу-1, пропанолу-2, 2-етиленгексанолу, нпропанолу. Дані засоби проявляють активну бактерицидну дію мікобактерій, грибів, вегетативних форм бактерій та оболонкових вірусів. Спиртові комбіновані засоби представлені 13 препаратами: Аеродизін 2000, ФХДЕЗ 3000, АХД 2000, Бацилол плюс, Декосепт, Деконекс, Стериліум, Октенідерм, Октеніспт, Саргосепт та ін.). Частка деззасобів даної групи складає 6,19\%. Механізм дії базується на денатурації білків та вимивання ліпідів 3 клітинної оболонки мікроорганізмів. Деззасоби на основі спиртів проявляють бактеріостатичні, туберкулоцидні та фунгіцидні властивості в 60-90 \% концентрації. Проте, в результаті випаровування швидко знижується концентрація і дезінфікуючі властивості засобів. Дані засоби не мають миючих властивостей, фіксують органічні забруднення та мають здатність пошкоджувати гуму та пластмас $[5,9,12,14]$.

Засоби на основі гуанідинових сполук (хлоргексидин) не схвалені в Європі для застосування в тваринництві. Засоби мають низьку віруліцидну активність та не ефективні при видаленні органічних речовин (Nolvasan, Hibiscrub, Hibitane, Savlon). Похідні гуанідинів активнодіючі речовини мають здатність утворювати бактерицидну плівку на поверхнях впродовж декількох діб. Деззасобів даної групи налічується 10 найменувань, що складає $4,76 \%$ я яких лише два $(20 \%)$ - вітчизняного виробництва $[5,13]$.

Фенольні препарати мають туберкулоцидну дію, високу ефективність проти вегетативних форм бактерій і мікроскопічних грибів та оболонкових вірусів. Особливістю даних речовин є здатність утворювати плівку на поверхнях, що забезпечує пролонговану дію на патогени. Головними недоліками фенольних сполук неприємний специфічний запах, токсичність та негативний вплив на довкілля. Ці аспекти в значній мірі обмежують застосування дезінфікуючих засобів даної групи $[5,11,13]$.

Арсенал засобів для ветеринарної дезінфекції постійно розширюється. Пошук i розробка нових антисептичних і дезінфікуючих препаратів ведеться в різних країнах світу. Постійна динаміка пошуку дезінфікуючих засобів обумовлена зростаючими вимогами споживачів щодо ефективності, зміною умов і технологій виробництва, сировинними можливостями, екологічної безпеки та питань мінімізації загальної токсичності. Зазначені критерії обмежують коло засобів на основі хімічних сполук, які можуть бути використані у виробництві нових дезінфектантів $[4,5,7,8,11,14]$.

Для раціонального застосування дезінфектантів рекомендується:

- використовувати діючі речовини 3 різних хімічних класів, що відрізняються механізмом дії на мікробні клітини;

- змінювати групи дезінфектантів у процесі роботи з інтервалом 3-6 міс;

- поточні обробки та генеральні прибирання проводити дезінфектантами 3 діючими речовинами різних хімічних груп;

- не занижувати концентрацію робочих розчинів;

- оптимізувати вибір дезінфектантів щодо дезінфекції. 


\section{В И С Н О В К И}

1. Кількість дезінфікуючих засобів за групами діючих речовин на ринку України понад 210 найменувань. Засоби представлені як вітчизняного, так і зарубіжного виробництва. Асортимент засобів для дезінфекції має тенденцію до збільшення.

2. Найбільша частка засобів представлена пінними і безпінними лужними засобами $31,43 \%$, пінні і безпінні кислотні засоби - 22,86 \%, дезінфектанти на основі четвертинних амонійних сполук (ЧАС) - 15,71 \%, спиртові - 6,19 \%, кисневмісні дезінфектанти - 5,24 \%, гуанідинові - 4,76 \%, засоби на основі альдегідів - 4,76 \%, хлорвмісні засоби - 4,29 \%.

Перспективи досліджень. Пошук і розробка комплексних дезінфікуючих засобів за критеріями широкого спектру антимікробної дії, відсутності токсичних властивостей, безпечності для персоналу тварин та зовнішнього середовища.

\section{ANALYSIS OF THE MARKET OF DISINFECTANTS IN UKRAINE}

\section{O. I. Kasianenko, A. V. Berezovskyi, S. M. Kasianenko, R. V. Dolbonosova}

Sumy National Agrarian University

160, Herasym Kondratiev, Sumy, 40021, Ukraine

\section{S U M M A R Y}

Number disinfectants groups of active substances on the market of Ukraine are more than 210 items of both domestic and foreign production. The largest share of drugs are represented foamy and without foamy alkaline agents. Their number is 66 items $(31.43 \%)$, including 17 ukrainian production. Approximately $22.86 \%$ (48 titles) range market Ukraine are foamy and with out foamy acid agents. With total agents of 20 disinfectants acid is produced in Ukraine. In veterinary practice widely used oxygen-containing disinfectants (11 items - $5.24 \%)$. The active oxygen is active substances in consisting of hydrogen peroxide, peroxide compounds, peracids, perborats, ozone and composite products based on them. Desinfectants based on aldehydes are some less represented in Ukraine - 10 means $(4.76 \%)$. High antimicrobial activity have organochlorine compounds. The nine drugs $(4.29 \%)$ presented in ukrainian market, only three of them produced in Ukraine. A large group (about 33 drugs - $15.71 \%$ ) are disinfectants based on quaternary ammonium compounds (QAC) consisting of hydrocarbon radicals, methyl, ethyl or benzene radical, chlorine, bromine, iodine. The proportion of alcohol means the group is $6.19 \%$. Means have low virulicidy activity and are not effective in removing organic substances. Arsenal tools for veterinary disinfection is constantly expanding. Finding and developing new antiseptics and disinfectants is worldwide. Permanent dynamic search disinfectants is caused by the increasing demands of consumers to efficiency, changing conditions and production technologies, raw features, safety and environmental issues to minimize overall toxicity.

Keywords: DISINFECTANTS, THE ACTIVE DRUG SUBSTANCEES, PATHOGENS, USE, PERFORMANCE.

\section{АНАЛИЗ РЫНКА ДЕЗИНФИЦИРУЮЩИХ СРЕДСТВ В УКРАИНЕ}

О. И. Касьяненко, А. В. Березовский, С. М. Касьяненко, Р. В. Долбоносова

Сумський национальный аграрный университет, ул. Герасима Кондратьева, 160, м. Сумы, 40021, Украина

\section{А Н Н О Т А ЦИ Я}

В статье приведены результаты анализа современного рынка дезинфицирующих средств по активно действующим веществам. На основе данных государственного реестра 
ветеринарных препаратов, кормовых добавок, готовых кормов и премиксов о зарегистрированных дезинфицирующих средств и их рецептур установлено, что количество препаратов для дезинфекции и санации объектов ветеринарно-санитарного надзора более 200 наименований, в том числе отечественного и зарубежного производства.

Наибольшая доля средств представлена пенными и беспенными щелочными средствами - 31,43 \%, пенные и беспенные кислотные средства - 22,86 \%, дезинфектанты на основе четвертичных аммонийных соединений (ЧАС) - 15,71 \%, спиртовые - 6,19 \%, кислородосодержащиеи дезинфектанты - 5,24 \%, гуанидины - 4,76 \%, средства на основе альдегидов - 4,76 \%, хлорсодержащие средства - 4,29 \%. Ассортимент средств дезинфекции на отечественном рынке имеет тенденцию к увеличению.

Ключові слова: ДЕЗИНФИЦИРУЮЩИЕ СРЕДСТВА, АКТИВНО ДЕЙСТВУЮЩИЕ ВЕЩЕСТВА, ПАТОГЕНЫ, ПРИМЕНЕНИЕ, ЭФФЕКТИВНОСТЬ.

\section{Л I T E P A T У P A}

1. Державний реєстр ветеринарних препаратів, кормових добавок, готових кормів та преміксів [Електронний ресурс] - Режим доступу http://vet.in.ua/menu/drugs.php?id_drugtype=7

2. Закон України «Про основні принципи та вимоги до безпечності та якості харчових продуктів» від 6 вересня 2005 р. № 2809-IV. (в редакції Закону № 1602-VII від 22.07.2014).

3. Сучасні проблеми дезінфектології та шляхи їх вирішення / А. П. Палій, А. І. Завгородній // Наук. вісн. Луган. нац. аграр. ун-ту. Сер. Ветеринарні науки. - Луганськ, 2011. - № 31. - С. 110-113.

4. Аналіз засобів для ветеринарної дезінфекції / М. С. Мандигра, А. В. Лисиця, С. В. Жигалюк та ін. // Ветеринарна медицина. - 2012. - Вип. 96. - С. 163-165.

5. Горжеєв B. M. Порівняльна характеристика дезінфікуючих засобів / В. М. Горженєв // Ветеринарна медицина. - 2013. - Вип. 97. - С. 180-181.

6. Дезінфекція і довкілля / М. С. Мандигра, А. В. Лисиця, Г. П. Воловик та ін. // Бюлетень «Ветеринарна біотехнологія». - 2018. - Вип. 32 (2) - С. 214-218.

7. Вершняк Т. В. Корозійні властивості засобів для санітарної обробки обладнання забійних цехів та харчової промисловості / Т. В. Вершняк, О. І. Касяненко // Наук.-техн. Бюлетень Інституту біології тварин і ДНДКІ ветпрепаратів та кормових добавок. - 2009. Вип.10. - С.108-112.

8. Кочюмбас I. Я. Сучасні засоби ветеринарної дезінфекції / I. Я. Коцюмбас, О. І. Сергієнко, Л. М. Ковальчик // Ветеринарна медицина України. - 2010. - № 11. - С. 36-26.

9. Загальні методи профілактики шляхом застосування комплексних дезінфікуючих засобів : [наук. посіб.] / [В. Л. Коваленко та ін.] ; Держ. наук.-контрол. ін-т біотехнології і штамів мікроорганізмів, Держ. наук. установа "Держ. центр інновац. біотехнологій", БНАУ Київ ; Ніжин : Лисенко М. М. [вид.], 2017. - 407 с.

10. Коваленко В. Л. Сучасні дезінфектанти на контролі біобезпеки // Ветеринарна біотехнологія. -2012. - Вип. 21. - С. 61-71.

11. Наукові та практичні аспекти дезінфекції у ветеринарній медицині [А.І. Завгородній, Б.Т. Стегній, А.П. Палій та ін.]. - Харків: НААН України, 2013 р. - 202 с.

12. Коваленко В. Л. Розробка і контроль дезінфікуючого засобу: монографія / В. Л. Коваленко, Д. А. Засєкін. - К.: ТОВ «НВП Інтерсервіс», 2013. - 240 с.

13. Проблеми ветеринарно-санітарної оцінки та дезінфекції на об'єктах м'ясопереробних підприємств / В. Л. Коваленко, О. В. Загребельний, Т. В. Бовкун, В. А. Куницький // Ветеринарна біотехнологія. - 2016. - № 28. - С. 101-108.

14. Дезінфекція і довкілля / М. С. Мандигра, А. В. Лисиця, Г. П. Воловик та ін. // Бюлетень «Ветеринарна біотехнологія». - 2018. - Вип. 32 (2). - С. 214-218. 


\section{References}

1. Derzhavnyi reiestr veterynarnykh preparativ, kormovykh dobavok, hotovykh kormiv ta premiksiv [Elektronnyi resurs] - Rezhym dostupu http://vet.in.ua/menu/drugs.php?id_drugtype=7

2. Zakon Ukrainy «Pro osnovni pryntsypy ta vymohy do bezpechnosti ta yakosti kharchovykh produktiv» vid 6 veresnia 2005 r. № 2809-IV. (v redaktsii Zakonu № 1602-VII vid 22.07.2014).

3. Palii, A. P., \& Zavhorodnii, A. I. (2011). Suchasni problemy dezinfektolohii ta shliakhy yikh vyrishennia [Suchasni problemy dezinfektolohii ta shliakhy yikh vyrishennia]. Nauk. visn. Luhan. nats. ahrar. un-tu. - The scientific journal in LNAU, № 31, S. 110-113. [in Ukrainian]

4. Analiz zasobiv dlia veterynarnoi dezinfektsii / Mandyhra M.S., Lysytsia A.V., Zhyhaliuk S.V., Dmytriiev I.M., Velychko Yu.M., Andrushchuk I.L., Mandyhra Yu.M., Romanishyna O.O. // Veterynarna medytsyna. - 2012. - Vyp. 96. - S. 163-165.

5. Horzheiev V. M. Porivnialna kharakterystyka dezinfikuiuchykh zasobiv // Veterynarna medytsyna. - Vyp. 97. - 2013. - S. 180-181.

6. Dezinfektsiia i dovkillia / Mandyhra M.S., Lysytsia A.V., Volovyk H.P., Mandyhra Yu.M., Boiko O.P. // Biuleten «Veterynarna biotekhnolohiia». - 2018. - Vyp. 32 (2) -S. 214-218.

7. Vershniak T.V. Koroziini vlastyvosti zasobiv dlia sanitarnoi obrobky obladnannia zabiinykh tsekhiv ta kharchovoi promyslovosti / T.V. Vershniak, O.I. Kasianenko // Nauk.-tekhn. Biuleten Instytutu biolohii tvaryn i DNDKI vetpreparativ ta kormovykh dobavok. - 2009. - Vyp.10. - S.108-112.

8. Suchasni zasoby veterynarnoi dezinfektsii / Kotsiumbas I.Ia., Serhiienko O.I.. Kovalchuk L.M. // Veterynarna medytsyna Ukrainy. - 2010. - № 11. - S. 36-26.

9. Zahalni metody profilaktyky shliakhom zastosuvannia kompleksnykh dezinfikuiuchykh zasobiv: [nauk. posib.] / [V. L. Kovalenko ta in.] ; Derzh. nauk.-kontrol. in-t biotekhnolohii i shtamiv mikroorhanizmiv, Derzh. nauk. ustanova "Derzh. tsentr innovats. biotekhnolohii", BNAU - Kyiv ; Nizhyn : Lysenko M. M. [vyd.], 2017. - 407 s.

10. Kovalenko V.L. Suchasni dezinfektanty na kontroli biobezpeky // Veterynarna biotekhnolohiia. -2012. - Vyp. 21. - S. 61-71.

11. Naukovi ta praktychni aspekty dezinfektsii u veterynarnii medytsyni / [A.I. Zavhorodnii, B.T. Stehnii, A.P. Palii ta in.]. - Kharkiv: NAAN Ukrainy, 2013 r. - 202 s.

12. Kovalenko V. L. Rozrobka i kontrol dezinfikuiuchoho zasobu: monohrafiia / V. L. Kovalenko, D. A. Zasiekin. - K.: TOV «NVP Interservis», 2013. - 240 s.

13. Kovalenko V.L. Problemy veterynarno-sanitarnoi otsinky ta dezinfektsii na obiektakh miasopererobnykh pidpryiemstv / V.L. Kovalenko, Zahrebelnyi O.V., Bovkun T.V., Kunytskyi V.A. // Veterynarna biotekhnolohiia. - № 28. - 2016. - S. 101-108.

14. Mandyhra M.S. Dezinfektsiia i dovkillia / M.S. Mandyhra, A.V. Lysytsia, H.P. Volovyk, Yu.M. Mandyhra, O.P. Boiko // Biuleten «Veterynarna biotekhnolohiia». - 2018. - Vyp. 32 (2) 2018. - S. 214-218.

Рецензент - Р. В. Петров, д. вет. н., професор, Сумський НАУ. 